\title{
Regulated Neurotrophin Receptor Responsiveness during Neuronal Migration and Early Differentiation
}

\author{
Beat Knüsel, ${ }^{1}$ Stuart J. Rabin, ${ }^{2}$ Franz Hefti, ${ }^{1}$ and David R. Kaplan' ${ }^{2}$ \\ 'Division of Neurogerontology, Andrus Gerontology Center and Department of Biological Sciences, University of Southern \\ California, Los Angeles, California 90089 and ${ }^{2}$ Eukaryotic Signal Transduction Group, ABL-Basic Research Program, \\ $\mathrm{NCl}$-Frederick Cancer Research and Development Center, Frederick, Maryland 21702
}

The response of brain tissue to neurotrophins during rat development was examined using a novel in vitro assay for Trk/neurotrophin receptor activity. In this assay, brain tissues were exposed to neurotrophins and ligand-induced Trk tyrosine phosphorylation was measured. During the perinatal period, Trk tyrosine phosphorylation in all brain areas was induced very similarly by the TrkB and TrkC ligands brainderived neurotrophic factor (BDNF), neurotrophin-3 (NT-3), and neurotrophin-4/5 (NT-4/5). In the adult brain, minimal signals were observed after treatment with these three factors, despite the continued presence of full-length and truncated TrkB protein. In contrast, responsiveness to the TrkA ligand NGF was absent in the embryo and increased during the first 2 weeks after birth in various brain areas, particularly in striatum, basal forebrain, and hippocampus. Our results, showing maximal responsiveness of brain tissue to BDNF, NT-3, and NT-4/5 during early neuronal differentiation and migration, suggest involvement of TrkB in these events. The lack of a significant response to these neurotrophins in the adult brain indicates effective posttranslational mechanisms that control the response of Trk family receptors. Our findings further demonstrate that neurons of the striatum and basal forebrain remain NGF responsive in the adult, confirming at the molecular level results obtained earlier at the cellular level for the basal forebrain cholinergic neurons.

[Key words: NGF, brain-derived neurotrophic factor, neurotrophin-3, neurotrophin-4/5, receptor tyrosine kinase, cholinergic brain neurons, Erk 1, phospholipase $C_{-\gamma} 1, S N T$, Alzheimer's disease]

The knowledge of neurotrophic factors, epitomized by NGF, has been greatly advanced by the discovery of the NGF relatives brain-derived neurotrophic factor (BDNF), neurotrophin-3 (NT3 ), and ncurotrophin-4/5 (NT-4/5) and the identification of several receptors for these factors (for reviews, see Barbacid et al., 1991; Chao, 1992; Ebendal, 1992). The transducing receptors for the neurotrophins form a family of structurally related pro-

\footnotetext{
Received Mar. 15, 1993; revised July 21, 1993; accepted Aug. 26, 1993.

We thank A. Rosenthal, J. W. Winslow, K. Nikolics, and L. E. Burton for NGF, BDNF, NT-3, and NT-4/5; D. Morrison for anti-Ptyr; J. Blenis for anti-Erk 1; and D. Soppet and L. Parada for anti-TrkB. This study was supported by NSF Grant BNS-9021255, by NIH Grants NS22933, AG09793, and AG10480, by a research grant from the National Parkinson Foundation (B.K. and F.H.), and by the National Cancer Institute, DHHS, under contract NO1-CO-74101 with ABL (S.J.R. and D.R.K.).

Correspondence should be addressed to Dr. Beat Knüsel, Andrus Gerontology Center, U.S.C., MC-0191, Los Angeles, CA 90089.

Copyright (C) 1994 Society for Neuroscience $0270-6474 / 94 / 141542-13 \$ 05.00 / 0$
}

teins, here collectively referred to as Trks, which share approximately 50\% sequence homology (Barbacid et al., 1991; Chao, 1992). The neurotrophins bind to and stimulate the intrinsic tyrosine kinase activity of different subsets of Trk receptors. In transfected cells and other cell lines, NGF binds to TrkA, BDNF to TrkB, NT-3 predominantly to TrkC and TrkB, and NT-4/5 to TrkB (Berkemeier et al., 1991; Kaplan et al., 1991a,b; Klein et al., 1991 a,b; Lamballe et al., 1991; Soppet et al., 1991; Squinto et al., 1991; Ip et al., 1992). High concentrations of NT-3 and NT-4/5 can induce TrkA activation in cell lines overexpressing this receptor (Berkemeier et al., 1991; Cordon-Cardo et al., 1991). The binding of neurotrophins to the Trk family receptors initiates a signaling cascade involving the phosphorylation of intracellular proteins on tyrosine residues (Kaplan et al., 1991b). These proteins include phospholipase C- $\gamma 1$ (PLC- $\gamma 1$ ), the 85 $\mathrm{kDa} / \mathrm{PI}-3$ kinase subunit, Nck, SHC, Erk 1 and 2, and SNT (Boulton et al., 1991; Kim et al., 1991; Miyasaka et al., 1991; Ohmichi et al., 1991; Vetter et al., 1991; Knüsel et al., 1992b; Park and Rhee, 1992; Raffioni and Bradshaw, 1992; RozakisAdock et al., 1992; Soltoff et al., 1992; Rabin et al., 1993).

The expression of the various members of the neurotrophin family in the rodent brain is relatively well studied at the level of their mRNA (Ernfors et al., 1990; Hofer et al., 1990; Klein et al., 1990b; Phillips et al., 1990; Wetmore et al., 1990; Lamballe et al., 1991). While NGF, NT-3, and NT-4/5 mRNAs are found in the brain and in many other anatomical areas, BDNF mRNA is predominantly localized in the brain and is considerably more abundant there than mRNA for the other neurotrophins (Leibrock et al., 1989; Ernfors et al., 1990; Hofer et al., 1990; Berkemeier et al., 1991; Ip et al., 1992; Timmusk et al., 1993). BDNF, NGF, and NT-3 mRNAs are heterogeneously distributed in the brain with a particularly high prevalence in the hippocampus (Ernfors et al., 1990; Hofer et al., 1990; Phillips et al., 1990). The brain distribution of NT-4/5 is presently unknown. During early development, transient peaks in the levels of NT-3 mRNA in hippocampus and cerebellum have been reported, contrasting with a steady increase in abundance of BDNF mRNA in both structures and of NGF mRNA in hippocampus (Maisonpierre et al., 1990). NT-3 expression in cerebellum has been associated with proliferating cerebellar neurons (Ernfors et al., 1992) and NT-3 protein was found to stimulate cerebellar granule neurons in culture (Segal et al., 1992).

Expression of $t r k \mathrm{~A}, t r k \mathrm{~B}$, and $t r k \mathrm{C} \mathrm{mRNA}$ in the embryonic, early postnatal, and adult rat brain suggests roles of these receptors and their ligands in the developing and mature organism. TrkA is localized mainly to the cholinergic neurons of the striatum and the basal forebrain, an important source of affer- 
ents to the hippocampus (Vazquez and Ebendal, 1991; Holtzman et al., 1992; Venero et al., 1993). TrkB and trkC mRNA are found more widespread in the brain but are most prominent in the hippocampus (Klein et al., 1990b; Ernfors et al., 1992; Merlio et al., 1992). During embryonic and early postnatal brain development mRNA for both $t r k \mathrm{~B}$ and $t r k \mathrm{C}$ has been found to transiently increase in abundance, peaking between postnatal day 1 (P1) and P14 in different brain areas (Ernfors et al., 1992; Dugich-Djordjevic et al., 1993; Ringstedt et al., 1993). Thus, their temporal pattern of expression does not strictly correspond to the pattern of NT-3 or BDNF expression (Maisonpierre et al., 1990). In contrast, $t r k \Lambda \mathrm{mRN} \Lambda$ in septum, stratum, and brainstem increases postnatally, being higher at 2 and 4 weeks of age than at 1 week, corresponding to the simultaneous increase of NGF mRNA (Maisonpierre et al., 1990; Ringstedt et al., 1993).

While changes in the levels and distribution of mRNA can provide important information about the mechanisms regulating neurotrophin function, this approach does not consider possible posttranscriptional regulatory events, the distribution of proteins, and the influence of the cellular environment on protein function. Indeed, inconsistencies observed between the known distribution of neurotrophin mRNAs and neurotrophin actions suggest effects of the cellular environment on Trk family receptor specificity. For example, while $t r k \mathrm{~B} \mathrm{mRNA}$ is localized on sympathetic neurons (Squinto et al., 1991; Schecterson and Bothwell, 1992), BDNF has not been found to act as a survival factor for these neurons (Lindsay and Rohrer, 1985). An approach to assess directly the activity of Trk proteins in primary cultures and established cell lines is to measure ligand-induced receptor tyrosine phosphorylation (Kaplan et al., 1991 b; Knüsel et al., 1992b). We have used this method to measure Trk tyrosine phosphorylation induced by NGF, BDNF, NT-3, and NT- $4 / 5$ in fresh rat brain tissue from embryonic age to adult life. We report pronounced regulation of neurotrophin responsiveness during brain development, differing for NGF and the other neurotrophins.

\section{Materials and Methods}

Tissue preparation and neurotrophin treatment. Embryos from timedprcgnant Wistar rats, or ncwborns and femalc postnatal animals of the same strain, were used for all experiments. The fetuses were removed at the appropriate embryonic (E) age $(\mathrm{E} 0=$ day of vaginal plug) from the deeply anesthetized (Nembutal, $0.6 \mathrm{ml} /$ animal) mothers and placed in cold PBS. Different brain areas were dissected in cold PBS according to published procedures (Hartikka and Hefti, 1988; Knüsel et al., 1990) and the tissues transferred to cold Krebs' medium equilibrated with $5 \%$ $\mathrm{CO}_{2}$ in $\mathrm{O}_{2}$ to maintain a $\mathrm{pH}$ of 7.4 at $37^{\circ} \mathrm{C}$. For tissue from postnatal animals, the rats were decapitated, the brain quickly removed and dissected, and the tissues placed in cold Krebs' medium. For each developmental age between one and four independent experiments were performed, and in each experiment tissue was pooled from between five animals (adult) to 80 animals (E15 embryos). The dissected tissues included cortex, hippocampus, striatum, basal forebrain, mesencephalon, and cercbellum. The tissucs were dissected using two fine tweezers. For brains 1 week postnatal or younger, a stereomicroscope was employed. First, cortex was collected that included the dorsal and lateral aspects of neocortex, consisting mostly of parietal cortex and caudal part of frontal cortex. Care was taken not to include the most rostral area. Next, hippocampus was dissected. The remaining cortical areas next to the caudate putamen were discarded and then the striatum separated from the rest of the brain. Basal forebrain was dissected next to include not only the septal area but also most of the hypothalamus. The cerebellar lobes were then carefully removed, and the mesencephalon was separated by two cuts rostral and caudal of superior and inferior colliculi, respectively. Last, the colliculi were cut off horizontally and only the ventral part of the mesencephalon was collected. After dissection the pooled tissue was briefly blotted with filter paper and then sliced twice at $90^{\circ}$ angles on a McIlwain tissue chopper (set at $0.25 \mathrm{~mm}$ ). The resulting microprisms were weighed and then transferred to $15 \mathrm{ml}$ centrifuge tubes containing $\mathrm{CO}_{2} / \mathrm{O}_{2}$-equilibrated $\mathrm{Krebs}$ medium at $37^{\circ} \mathrm{C}$ in a water bath and the tubes tightly capped. Approximately 600-700 $\mathrm{mg}$ of fresh tissue (wet weight) was placed in each tube. The Krebs' medium was replaced three times in 15 min intervals with freshly gassed medium by aspirating the supernatant and squirting fresh medium with enough force to resuspend the settled microprisms completely. While the first supernatants were turbid from cell debris, the repeated washes finally yielded a suspension of microprisms in clear Krebs' medium. Inspection under the microscope confirmed uniform width of the microprisms of approximately $250 \mu \mathrm{m}$ and a length of between approximately 0.5 and $2 \mathrm{~mm}$. Fifteen minutes after the last wash the supernatant was replaced with fresh Krebs' medium to give a suspension of $100 \mathrm{mg}$ of wet weight tissue per milliliter of medium when possible, but not less than $5 \mathrm{ml}$ of medium per tube. The tissue was resuspended by gentle trituration with a disposable plastic pipette and then, using a cut-off 1 $\mathrm{ml}$ pipette tip, immediately aliquoted in five $800 \mu \mathrm{l}$ aliquots into microfuge tubes placed in a dry bath at $37^{\circ} \mathrm{C}$. The tubes were closed and the tissuc picces wcre allowed to settle for $10 \mathrm{~min}$. The medium was replaced a final time with fresh gassed Krebs' medium at $37^{\circ} \mathrm{C}$ containing $5 \%$ heat-inactivated horse serum (GIBCO) to give a total volume per tube of $300 \mu 1$. Neurotrophins were then immediately added as indicated for each experiment. The tubes were closed and, after 4 min incubation at $37^{\circ} \mathrm{C}$ placed on ice, quickly centrifuged for $10 \mathrm{sec}$, and the medium removed. Lysis buffer $(0.5 \mathrm{ml} ; 137 \mathrm{~mm} \mathrm{NaCl}, 20 \mathrm{~mm}$ Tris pH $8.0,1 \%$ Triton X-100, 10\% glycerol, $1 \mathrm{~mm}$ phenylmethylsulfonyl fluoride, 500 $\mu \mathrm{M}$ orthovanadate) was added and the samples sonicated for 2-3 sec using an immersed probe. The samples were then gently rocked at $4^{\circ} \mathrm{C}$ for $20 \mathrm{~min}$ and subsequently centrifuged for $10 \mathrm{~min}$ at $10,000 \times \mathrm{g}$. The supernatant was transferred to a fresh microfuge tube and frozen at $-70^{\circ} \mathrm{C}$. Five microliters of supernatant were retained for analysis of total protein. Recombinant human NGF, BDNF, NT-3, and NT-4/5 used in the present study were kindly provided by A. Rosenthal, J. W. Winslow, K. Nikolics, and L. E. Burton of Genentech, Inc. (South San Francisco, CA). Biological activity of the preparations of factors used was confirmed with detailed studies on CNS and PNS neurons (data not shown).

Immunoprecipitation and Western blotting. Trk family proteins were immunoprecipitated with rabbit anti-pan Trk 203 (Hempstead et al., 1992). Anti-pan Trk 203 was generated to the 14 amino-terminal amino acids of human TrkA as described (Martin-Zanca et al., 1989). This antibody reacts with TrkA (Kaplan et al., 1991a,b) and antibodies generated against this peptide have been demonstrated to react with TrkB and TrkC (Lamballe et al., 1991; Soppet et al., 1991). Anti-TrkB antibody 442 was provided by D. Soppet and L. Parada (NCI-FCRDC) or was generated to amino acids 45-60 in the extracellular domain of rat TrkB as described (Soppet et al., 1991). The anti-TrkB antibody does not recognize TrkA (Soppet et al., 1991; D. R. Kaplan, unpublished observations). Anti-phosphotyrosine (anti-PTyr) mouse monoclonal antibody 4 G10 was provided by D. Morrison (NCI-FCRDC) and was used as described (Kaplan et al., 1990, 1991b). Intracellular target proteins were immunoprecipitated with mouse anti-PLC- $\gamma 1$ (Suh et al. 1988 ) or rabbit anti-Erk 1 (Chen et al., 1992). SNT was precipitated using p1 $3^{\text {sucl }}$ coupled to agarose as described (Rabin et al., 1993).

Immunoprecipitation and Western blotting were as previously described (Kaplan et al., 1990, 1991b). Protein content was determined using the Bio-Rad protein assay kit. Immunoprecipitations were performed for 3-4 hr at $4^{\circ} \mathrm{C}$. Precipitates were collected with protein A-Sepharose, and washed three times with lysis buffer and once with water. The iminunoprecipitates were boiled in sample buffer ( $2 \%$ SDS, 100 mM dithiothrcitol, $10 \%$ glycerol, and $0.25 \%$ bromophenol blue) for 5 min and electrophoresed on 7.5\% SDS-polyacrylamide (PAGE) minigels before transfer to nitrocellulose. Protein blots were probed overnight at $4^{\circ} \mathrm{C}$ with culture supernatant from $4 \mathrm{G} 10$ monoclonal antibody-producing cells diluted $1: 1$ with Tris-buffered saline with a final concentration of $0.2 \%$ Tween-20, or with anti-pan Trk 203 . Blots were analyzed using an ECL chemiluminescence system (Amersham Corp., Arlington Heights, IL). To assay TrkB, lysates were precipitated with $75 \mu$ l of wheat germ lectin agarose (Pharmacia) for $3 \mathrm{hr}$ at $4^{\circ} \mathrm{C}$. Precipitates were washed as described above, electrophoresed by $7.5 \%$ SDS-PAGE, transferred to nitrocellulose, and probed with anti-TrkB. 

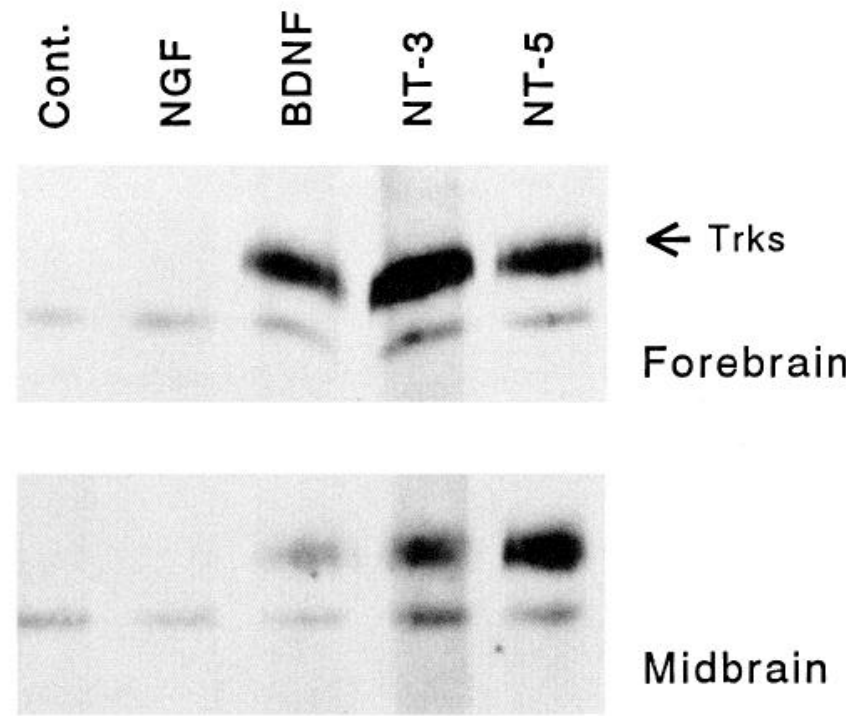

\section{Midbrain}

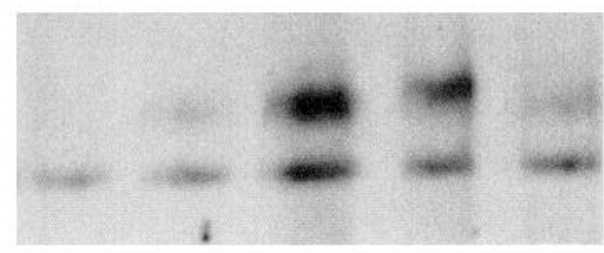

\section{Body}

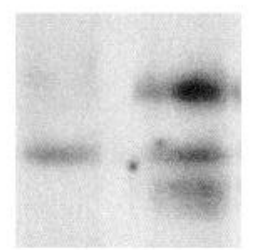

\section{Body, triturated}

Figure 1. Neurotrophin-induced Trk tyrosine phosphorylation in brain tissue at E13. Brains from $38 \mathrm{E} 13$ embryos were dissected into forebrain and mesencephalon. Microslices of these tissues and of the body of the embryos were prepared on a tissue chopper and incubated for $4 \mathrm{~min}$ at $37^{\circ} \mathrm{C}$ with maximally effective concentrations of NGF $(100 \mathrm{ng} / \mathrm{ml}), \mathrm{BDNF}$ $(200 \mathrm{ng} / \mathrm{ml})$, NT $-3(400 \mathrm{ng} / \mathrm{ml})$, or NT $-4 / 5(200 \mathrm{ng} / \mathrm{ml})$. After incubation the tissue was lysed and immunoprecipitated with anti-pan Trk serum. Trk proteins were subjected to SDS-PAGE and analyzed by immunoblotting with anti-Ptyr. For one control and one NGF-treated sample, microslices of body tissue were additionally mechanically disrupted by trituration immediately preceding the incubation period.

Quantification of the phosphorylation data. In order to compare signals obtained in different experiments, standards were prepared by pooling and subsequently aliquoting lysate from BDNF-treated embryonic (E19) forebrain. For each experiment, the phosphotyrosine content of the Trks in one of these standards was analyzed with the other samples. To assess quantitatively the different phosphorylation signals, several sheets of $\mathrm{x}$-ray film were exposed to each blot for varying lengths of time between $30 \mathrm{sec}$ and $10 \mathrm{~min}$. The bands on the developed films were quantified utilizing the video-based BIOQUANT MEGx IV Image Analysis System (R \& M Biometrics, Inc., Nashville, TN). The system identifies objects within a user-defined window, measures the brightness of each pixel and the total area of the objects, and calculates their mean optical densities. A window size was chosen to include one band for each measurement. For each band an index of precipitated silver in the film's emulsion was calculated as the product of mean optical density and area of the band. Averaging these values from each film exposed to the same blot, and corrected by the exposure time of the film, a relative amount of Trk tyrosine phosphorylation signal was estimated for each sample. Only values within the linear range of the film were used for this calculation. Final tissue-specific response values were calculated by correcting these tyrosine phosphorylation amounts by the total amount of protein in the samples and by the response value of the standard sample in the same assay. To verify the validity of our quantification approach, we prepared a serial dilution of lysate from BDNF-stimulated P2 cortex in lysate from identical but unstimulated samples. Quantification of the respective bands established a linear relationship between the proportion of tyrosine-phosphorylated Trk protein and the signal as determined by our method (see Results, Fig. 3).

\section{Results}

Assay for neurotrophin-induced Trk tyrosine phosphorylation in embryonic and adult rat brain tissues

The activity of Trk family receptors was measured by phosphotyrosine antibody detection of ligand-induced receptor auto (trans)-phosphorylation of immunoprecipitated Trk-type proteins in Western blots. Since the Trk antibody used was generated against sequences shared by all full-length Trks (anti-pan Trk; see Materials and Methods), this method recognizes tyrosine phosphorylation of all known signal-transducing neurotrophin receptors. Microprisms of different brain areas prepared from rats between E13 and P240 were incubated under physiological conditions with NGF, BDNF, NT-3, or NT-4/5, using concentrations of the factors resulting in maximal effects on CNS neurons (Knüsel et al., 1991; Widmer et al., 1992, 1993). Figure 1 shows the result of an experiment with tissue of the earliest developmental age studied. At this stage, the brains were dissected into forebrain and mesencephalon only, due to their small size and relatively undifferentiated state. Additional samples from these early embryos were prepared from the complete body without head. BDNF, NT-3, and NT-4/5 induced strong Trk tyrosine phosphorylation in forebrain and mesencephalon of the E13 rat embryos (Fig. 1). Moderate responses to BDNF, NT-3, and NT-4/5 were also detected in the body. No signal was observed in NGF-treated tissues from rat brain, although a weak response was seen in the body. Mechanical disruption of the tissue by forceful trituration through a $1 \mathrm{ml}$ plastic pipette tip before incubation with trophic factor enhanced the NGFinduced Trk tyrosine phosphorylation signals in the body (Fig. 1), most likely by increasing the penetration of the neurotrophin to the site of Trk receptors.

In contrast to the high levels of BDNF-, NT-3-, and NT-4/ 5 -induced Trk tyrosine phosphorylation signals observed in embryonic brain tissue, at P240 little or no tyrosine phosphorylation of Trks could be detected using these factors in six different brain areas. The signals in BDNF- and NT-3-treated samples were indistinguishable from the signals observed in control samples (Fig. 2). However, unlike the response patterns observed in embryonic brain, in adult brain a clear NGF-induced signal was detected, most notably with striatum, hippocampus, and basal forebrain. In other experiments using adult brain tissue, particularly hippocampus, occasionally weak but clearly identifiable signals could be seen after BDNF incubation. However, these signals, unlike the ones observed in BDNFtreated embryonic tissue, were barely detectable (data not shown). The specificity of the observed phosphorylation signals was tested by incubating lysates of BDNF-treated samples from embryonic brain with either preimmune serum or anti-pan Trk in the presence of the peptide against which the antibody was raised. Under both conditions, no Trk tyrosine phosphorylation was detected. To visualize the presence of Trk protein in the samples, some blots were reprobed with either anti-pan Trk or specific anti-TrkB antibodies. Similar amounts of Trk proteins were present in lanes corresponding to treated and untreated 


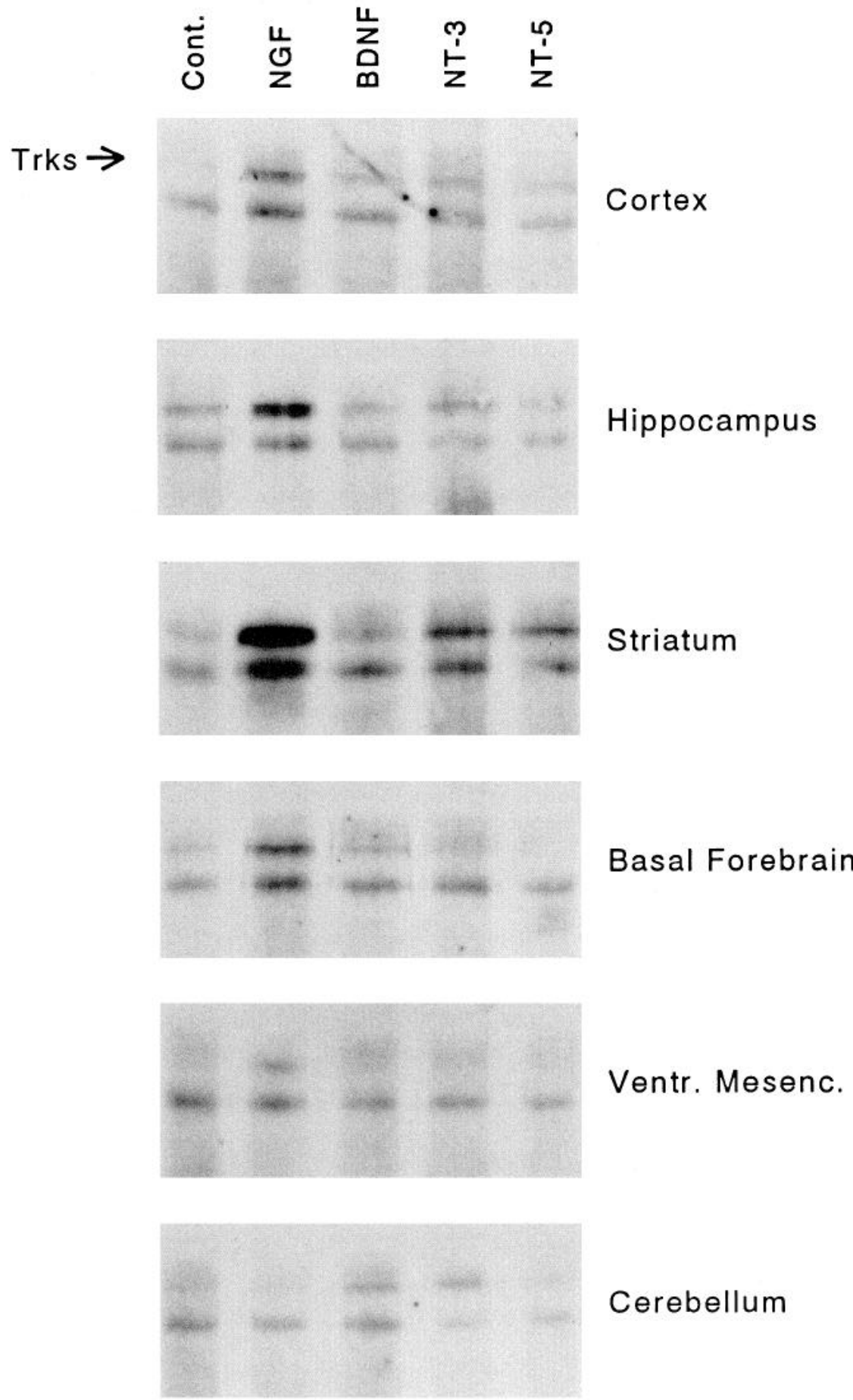

Figure 2. Neurotrophin-induced Trk tyrosine phosphorylation in adult brain of P240. Cortex, hippocampus, striatum, basal forebrain, ventral mesencephalon, and cerebellum were dissected from six rats at P240. Microslices of these tissues were incubated for $4 \mathrm{~min}$ at $37^{\circ} \mathrm{C}$ with maximally effective concentrations of NGF, BDNF, NT-3, or NT $-4 / 5$ as for Figure 1. Shown are Western blots of Trk immunoprecipitates probed with anti-Ptyr. The pattern of tyrosine phosphorylation of Trks observed in this experiment is characteristic for the pattern seen with brain tissue of at least 6-8 weeks of age.

samples, demonstrating that neurotrophin treatment did not affect the amount of immunoprecipitable proteins but only the extent of tyrosine phosphorylation of these proteins (data not shown).

The distinct patterns of neurotrophin responses in embryonic or adult brain tissues proved to be remarkably stable. These patterns were unaltered by mechanical disruption of the tissue using $1 \mathrm{ml}$ plastic pipette tips or by suspension of the slices for several hours at physiological temperature in gassed Krebs' medium. The lack of adult response to BDNF was not due to degradation of the trophic factor since preincubation of BDNF with adult tissue did not reduce its effectiveness when subsequently tested with embryonic tissue (data not shown). To rule out the possibility of inadequate penetration of factors, insufficient concentration, or effects of incubation time and temperature as reasons for the lack of a significant BDNF or NT-3 response in adult tissue, we performed assays under various conditions. Tissue was mechanically disrupted by forceful trituration, followed by treatment with up to $10 \mu \mathrm{g} / \mathrm{ml}$ of BDNF. In addition, incubation times between $4 \mathrm{~min}$ and $1 \mathrm{hr}$ and temperatures of $23^{\circ} \mathrm{C}$ and $37^{\circ} \mathrm{C}$ were examined. Finally, samples were also incubated at $4^{\circ} \mathrm{C}$ for $2 \mathrm{hr}$ as used in cross-linking 

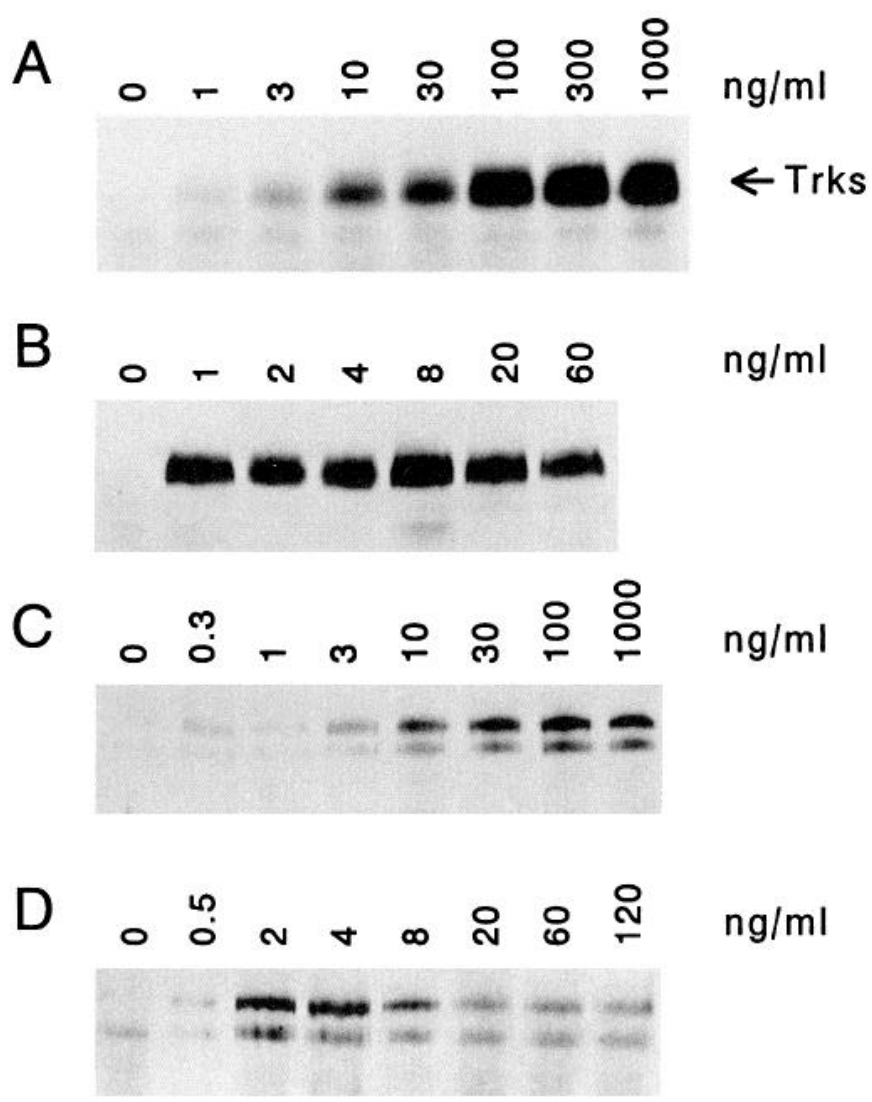

Figure 3. The BDNF response in early postnatal cortex and the NGF response in adult striatum are dose and time dependent. Tissue samples of $\mathrm{P} 2$ rat cortex and $\mathrm{P} 76$ adult striatum were incubated with BDNF or $\mathrm{NGF}$, respectively, and lysed, and the lysates were immunoprecipitated with anti-pan Trk. Western blots of the Trk proteins were probed with anti-Ptyr. For dose-response determinations for BDNF $(A)$ and NGF $(C)$, tissues were treated with the indicated concentrations of factor for $4 \mathrm{~min}$ at $37^{\circ} \mathrm{C}$. For time course experiments, tissues were treated for the indicated times with $200 \mathrm{ng} / \mathrm{ml} \operatorname{BDNF}(B)$ or $100 \mathrm{ng} / \mathrm{ml} \mathrm{NGF}(D)$ at $37^{\circ} \mathrm{C}$.

experiments (Soppet et al., 1991; Escandon et al., 1993), or for $2 \mathrm{hr}$ at $4^{\circ} \mathrm{C}$ followed by an additional $2 \mathrm{~min}$ at $37^{\circ} \mathrm{C}$. None of these procedures resulted in an increased response to BDNF if compared to the results with standard incubations for $4 \mathrm{~min}$ at $37^{\circ} \mathrm{C}$. We conclude from our findings that in tissue from different brain regions, a minimal level of responsiveness to BDNF (and probably NT-3 and NT-4/5) is present in the adult but that this responsiveness is much lower than during early neuronal development and lower than the response to NGF in adult tissue. In most samples of adult tissue, including untreated controls, we noted low levels of tyrosine phosphorylation at the molecular weight corresponding to the characteristic band induced by NGF (Fig. 2). This level of constitutive phosphorylation may reflect intrinsic Trk activity due to the presence of endogenous NGF. In the experiment shown in Figure 2, as well as in other experiments, we also noted a second band at approximately $120 \mathrm{kDa}$. The intensity of this band, which was recognized by both antiPtyr and anti-Trk antibodies (data not shown), appeared to correlate best with the intensity of the NGF-induced $140 \mathrm{kDa}$ Trk phosphotyrosine band (see also Figs. 3, 5). This band may represent a breakdown product of Trk that might arise physiologically after ligand binding and Trk stimulation, or alternatively, during tissue extraction or immunoprecipitation.
The Trk tyrosine phosphorylation response in brain tissue is dose and time dependent

A time- and dose-response analysis for the Trk tyrosine phosphorylation mediated by BDNF in microprisms of P2 cortex and by NGF in adult striatum was performed to analyze further the specificity of the observed responses. The effects of both neurotrophins were dose and time dependent. Weak Trk tyrosine phosphorylation signals were detected at $3 \mathrm{ng} / \mathrm{ml} \mathrm{BDNF}$, with half-maximal responses at $30 \mathrm{ng} / \mathrm{ml}$ and maximal responses at $100 \mathrm{ng} / \mathrm{ml}$ (Fig. $3 A$ ). These concentrations are similar to the BDNF concentrations required to induce increases in the activity of the cholinergic marker enzyme ChAT in cultures of embryonic basal forebrain (Alderson et al., 1990; Knüsel et al., 1991) or to stimulate phosphatidylinositol breakdown and phosphorylation of PLC $-\gamma 1$ in cultures of embryonic cortical cells (Widmer et al., 1992, 1993). The Trk tyrosine phosphorylation response to BDNF in early postnatal brain tissue was very rapid, with maximal signals observed already after $1 \mathrm{~min}$. This maximal level was maintained for 5-10 min before gradually declining (Fig. $3 B$ ). NGF treatment of adult striatal microslices resulted in detectable Trk tyrosine phosphorylation at $3 \mathrm{ng} / \mathrm{ml}$ of the factor and maximal levels were achieved at $30 \mathrm{ng} / \mathrm{ml}$ (Fig. $3 C$ ). The preparation of recombinant human NGF used in this study is maximally effective in inducing physiological responses in primary cultures of rat basal forebrain cholinergic neurons and chick dorsal root ganglion cells at a concentration of $1 \mathrm{ng}$ $\mathrm{ml}$ (Knüsel et al., 1991). Similar concentrations were found to induce the tyrosine phosphorylation of Trk in basal forebrain cultures (Knüsel et al., 1992b). Thus, significantly higher concentrations were required to stimulate the tyrosine phosphorylation of Trk maximally in adult striatal tissue. The NGF-induced tyrosine phosphorylation of Trks also was time dependent. In microprisms incubated with $100 \mathrm{ng} / \mathrm{ml} \mathrm{NGF}$, tyrosine phosphorylation of Trk was detected after $30 \mathrm{sec}$ of treatment and was maximal between 2 and $4 \mathrm{~min}$ (Fig. 3D). The response then gradually declined and by $2 \mathrm{hr}$ was $36 \%$ of the maximal response as determined by optical density measurement (see below). These results are similar to the time course of Trk tyrosine phosphorylation responses observed in NGF-treated PC12 cells (Kaplan et al., 1991b).

\section{Quantification of neurotrophin receptor tyrosine phosphorylation}

To quantify Trk tyrosine phosphorylation in neurotrophintreated tissues, films exposed to the chemiluminescence signal were optically scanned and the values obtained were corrected for the amount of total protein in the tissue samples. Results were then standardized to the signal of BDNF-treated embryonic sample aliquot included in each experiment. To validate the quantification method, lysate from BDNF-treated embryonic tissue samples was serially diluted with lysate from untreated samples. Trk proteins were then assessed for ligandinduced tyrosine phosphorylation (Fig. 4). The results indicate a linear relationship between the percentage of BDNF-stimulated lysate and the Trk tyrosine phosphorylation signal measured by our method.

The responsiveness of brain tissue to $N G F, B D N F, N T-3$, and NT-4/5 shows a distinct developmental pattern

In the rat, much of the development of the brain and its intricate neuronal circuitry occurs during the last days of pregnancy and 
the first few weeks after birth (Jacobson, 1991). To determine at which developmental stage neurotrophin responsiveness changes from an embryonic to an adult pattern, we performed Trk tyrosine phosphorylation assays with tissue aged between E15 and P31 (Fig. 5). For most stages of brain development these assays included cortex, hippocampus, striatum, basal forebrain, ventral mesencephalon, and cerebellum. The gradual transition from an embryonic to an adult response pattern for the different neurotrophins was most clearly evident in striatum and hippocampus and was similar in other brain areas examined. From E15 through P7, high levels of Trk tyrosine phosphorylation were observed in all brain samples treated with BDNF, NT-3, or NT-4/5. This response declined sharply between $\mathrm{P} 10$ and $\mathrm{P} 14$, and subsequently decreased to nearly undetectable levels. Small responses persisted at P21 and P31 in the cerebellum. Reprobing of blots with anti-pan Trk or specific anti-TrkB antibodies showed that variations between the responses to these three neurotrophins, as occasionally observed in individual experiments (see Fig. 5, E19 striatum), were closely related to the variations in amounts of Trks in individual lanes (data not shown). Quantification of the data by optical density measurements, as outlined in Materials and Methods and illustrated in Figure 4, confirmed that in all tissues the responses to BDNF, NT-3, and NT-4/5 were similar to each other but distinct from the response to NGF (Fig. 6). This similarity of the responses to all three TrkB ligands suggests that the signals observed with these factors predominantly represent activation of TrkB. In mesencephalon, cortex, and cerebellum, three areas that for anatomical reasons allow selective dissection at a relatively early stage of development, the response to ligands of TrkB, showed a sharp initial increase and subsequent rapid decrease. The order of maximal responses in these brain areas parallels the order of their maturation and their exact times coincide well with the periods of maximal migration of newly generated neurons in the respective brain areas (Jacobson, 1991).

NGF-induced Trk tyrosine phosphorylation gradually appeared postnatally in some tissues and by 2 weeks of age had reached maximal levels (Figs. 5, 6). Adult NGF responses were maximal in the striatum. More moderate signals were observed in hippocampus and basal forebrain and very weak signals in some experiments in cortex, mesencephalon, and cerebellum (Figs. 5, 6). The pronounced NGF response in the striatum did not decline throughout adult life up to the age of 8 months (Fig. 6). NGF-induced tyrosine phosphorylation of Trk-type proteins in mesencephalon and cerebellum, two brain areas that are not known to contain cell bodies or terminals of NGF-responsive CNS neurons (Vazquez and Ebendal, 1991; Holtzman et al., 1992), might reflect signaling in sympathetic fibers associated with the brain vasculature rather than in NGF-responsive central neurons. In all brain areas, the maximal levels of NGF-induced Trk tyrosine phosphorylation were less than the maximal levels induced by BDNF, NT-3, or NT-4/5 during embryonic and early postnatal development (Figs. 5, 6).

At developmental times and in tissues where responses to all neurotrophins were observed in identical samples (see Fig. 5, P7 hippocampus and striatum), the NGF-induced tyrosinephosphorylated Trk band migrated faster and was significantly narrower than the bands observed after BDNF, NT-3, or NT$4 / 5$ stimulation (Fig. 5 and data not shown). This characteristic difference in the appearance of the phosphotyrosine bands induced by TrkA or TrkB ligands might reflect the potentially higher amounts of TrkB than TrkA in our samples or, alter-
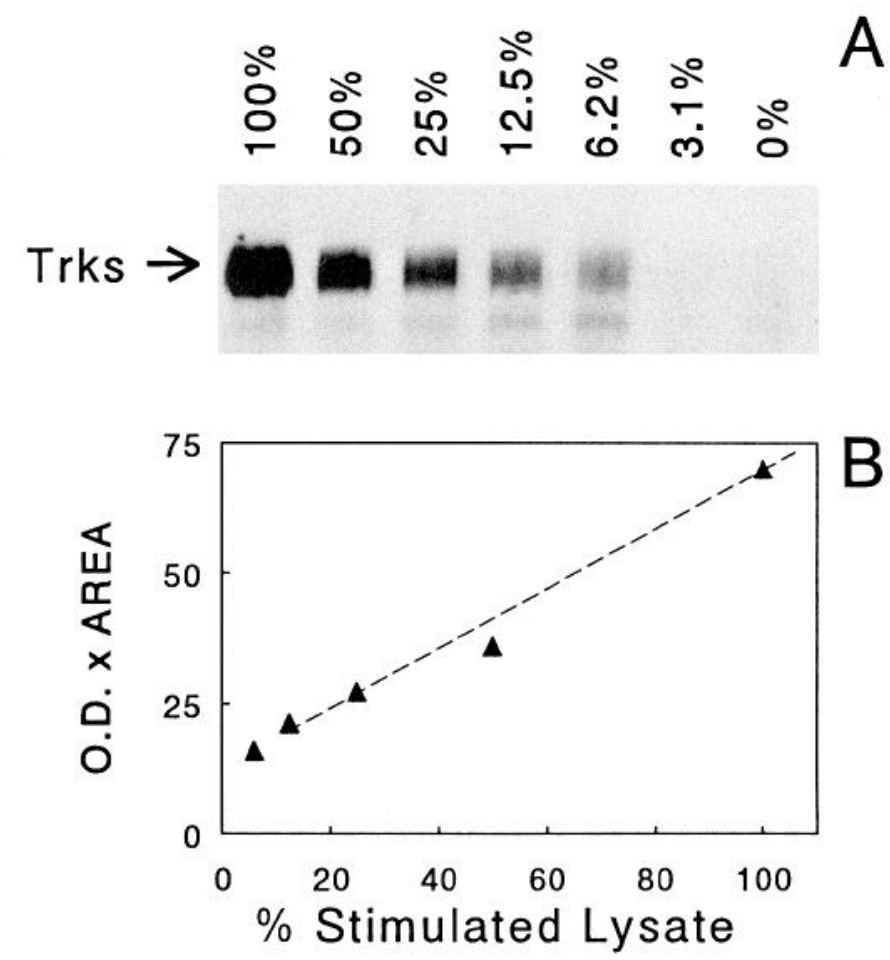

Figure 4. Quantification of data. Linear relationship was determined between the amount of lysate used for immunoprecipitation and the Trk tyrosine phosphorylation signal. $A$, Lysate from BDNF-treated (200 $\mathrm{ng} / \mathrm{ml}$ ) embryonic (E20) brain samples was serially diluted with lysate from untreated samples, and Trk proteins were assessed for ligandinduced tyrosine phosphorylation. Shown is a Western blot of Trk immunoprecipitates probed with anti-Ptyr. $B$, The data in $A$ was quantitated by optically scanning films as described in the Materials and Methods. Optical density $(O . D$.) values (vertical axis) are plotted against the percentage of BDNF-stimulated lysate per total (stimulated and unstimulated) lysate.

natively, may demonstrate possible microheterogeneity of the TrkB proteins.

\section{TrkB expression in embryonic and adult brain tissue}

A possible explanation for the lack of TrkB tyrosine phosphorylation responses in adult cortex treated with BDNF is absence of this receptor from the tissue, despite the demonstrated presence of its mRNA (Klein et al., 1990b; Vazquez and Ebendal, 1991; Merlio et al., 1992). Therefore, cortical tissue aged from E16 through P145 was assayed for the expression of TrkB using a TrkB-specific antibody. This antibody was generated to extracellular sequences of rat TrkB and therefore recognizes both full-length and truncated ( $\mathrm{gp} 95^{\mathrm{r} k \mathrm{~B}}$ ) TrkB receptors. Full-length TrkB and a wide band at $95 \mathrm{kDa}$ corresponding in size to truncated TrkB were present in embryonic and postnatal cortex (Fig. 7). This lower-molecular-weight species is most likely a truncated form of TrkB, as it was recognized only by antibodies that recognize extracellular and not intracellular TrkB sequences (data not shown). While the expression of both full-length and truncated TrkB increased during embryonic development, only the expression of the truncated form continued to increase until 34 weeks after birth. This difference resulted in a change of the ratio of truncated to full-length TrkB in the cortex from approximately $1: 1$ at E18 and E20, the times of maximal response in cortex, to $4: 1$ at P31, as determined by densitometry (data 


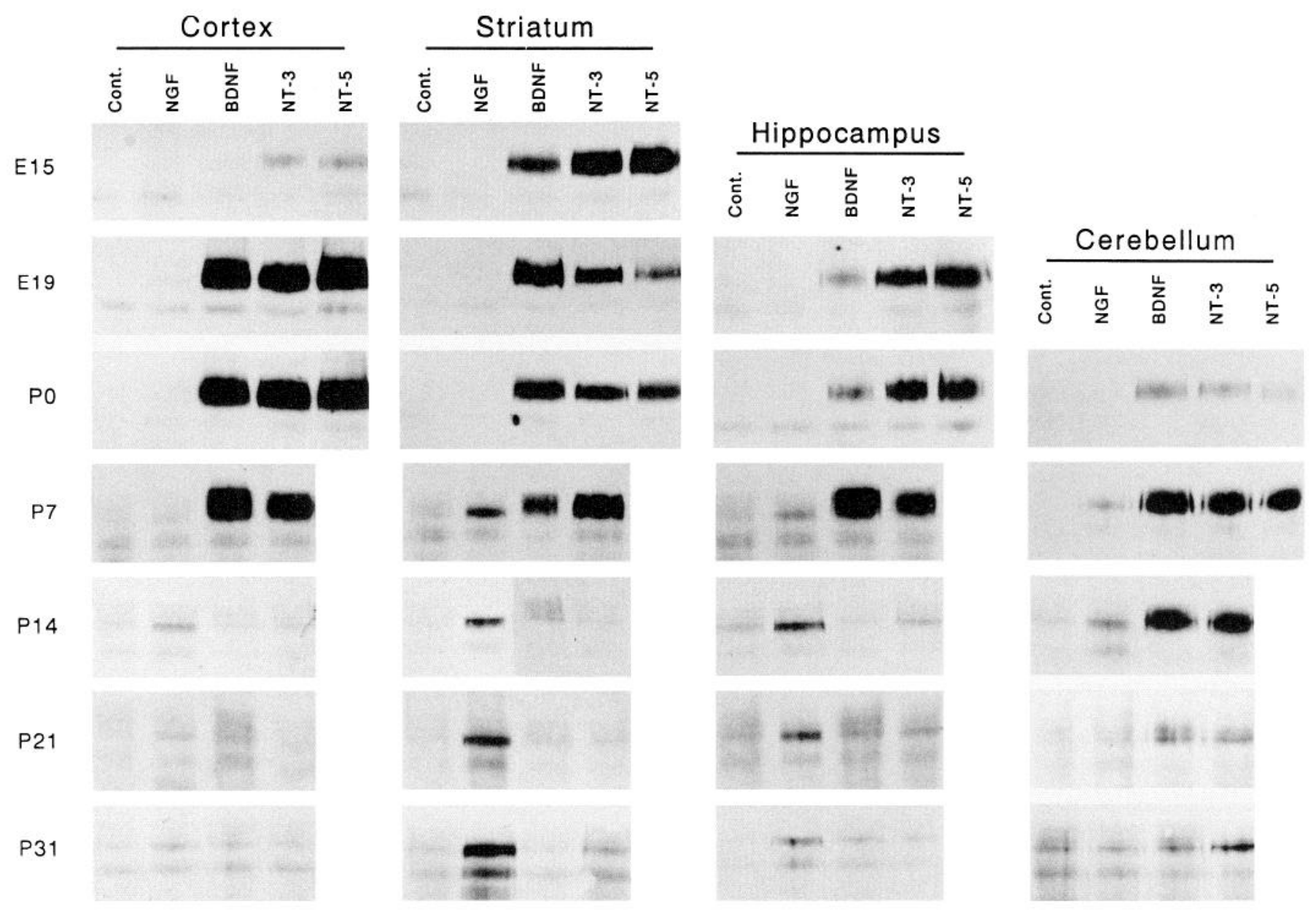

Figure 5. Developmental changes of specific neurotrophin-induced Trk tyrosine phosphorylation responses in rat brain. Cortex, striatum, hippocampus, and cerebellum were dissected from rats aged between E15 and P31. Microslices of the tissues were incubated for 4 min with maximally effective concentrations of NGF, BDNF, NT-3, or NT-4/5 as for Figure 1. After incubation the tissue was lysed and immunoprecipitated with anti-pan Trk serum. Trk proteins were subjected to SDS-PAGE and analyzed by immunoblotting with anti-Ptyr. Note the similar responses to BDNF, NT-3, and NT-4/5. Differences between the signals induced by these neurotrophins in individual experiments were closely related to the amount of Trks in individual lanes (see Results).

not shown). In addition to this increase in relative abundance, the truncated TrkB receptor after age P7 appeared to be composed of multiple forms (Fig. 7).

\section{Neurotrophin stimulation of brain slices results in tyrosine phosphorylation of intracellular target proteins}

Binding of neurotrophins to Trk family receptors stimulates within minutes the tyrosine phosphorylation of several intracellular target proteins, including PLC- $\gamma 1$, Erk 1, and SNT (Boulton et al., 1991; Kim et al., 1991; Miyasaka et al., 1991; Vetter et al., 1991; Knüsel et al., 1992b; Rabin et al., 1993). SNT is phosphorylated on tyrosine in neuronal cells treated with neurotrophic factors but not with mitogens (Rabin et al., 1993). We assayed for tyrosine phosphorylation of these proteins in embryonic cortex and adult hippocampus. Cortex from embryonic tissue was chosen since it can be easily collected in relatively large quantity and since its response to BDNF, NT-3, and NT$4 / 5$ was most pronounced. Adult hippocampus not only contains terminals of NGF-responsive basal forebrain cholinergic neurons but is also known to express mRNA for $t r k \mathrm{~B}$ and $t r k \mathrm{C}$ and for the neurotrophins BDNF and NT-3 at high levels. As expected, incubation of embryonic tissue with BDNF or NT-3, but not with NGF, induced the tyrosine phosphorylation of PLC- $\gamma 1$, Erk 1, and SNT (Fig. 8 and data not shown). No effects, however, on phosphorylation of SNT were seen in adult tissue treated with neurotrophins, including NGF (Fig. $8 A$ ). In contrast, NGF in adult tissue induced an approximately twofold increase in the tyrosine phosphorylation of Erk 1 (Fig. $8 B$ ) while the observed relative increase over the high level of constitutive PLC- $\gamma 1$ tyrosine phosphorylation was minimal (Fig. 8C). Incubation of adult brain slices with BDNF or NT-3 did not induce tyrosine phosphorylation in PLC- $\gamma 1$, Erk 1, or SNT (data not shown). Thus, neurotrophin-induced activation of Trks was reflected in tyrosine phosphorylation of many but not all examined targets of neurotrophin action.

\section{Discussion}

In this report, we introduce a method to assess neurotrophin receptor responsiveness in fresh brain tissue based on the measurement of ligand-induced receptor tyrosine autophosphorylation. Using this technique, we observed pronounced developmental changes of neurotrophin responsiveness in different areas of rat brain. During early development, the TrkB ligands BDNF, NT-3, and NT-4/5, but not the TrkA ligand NGF, in- 

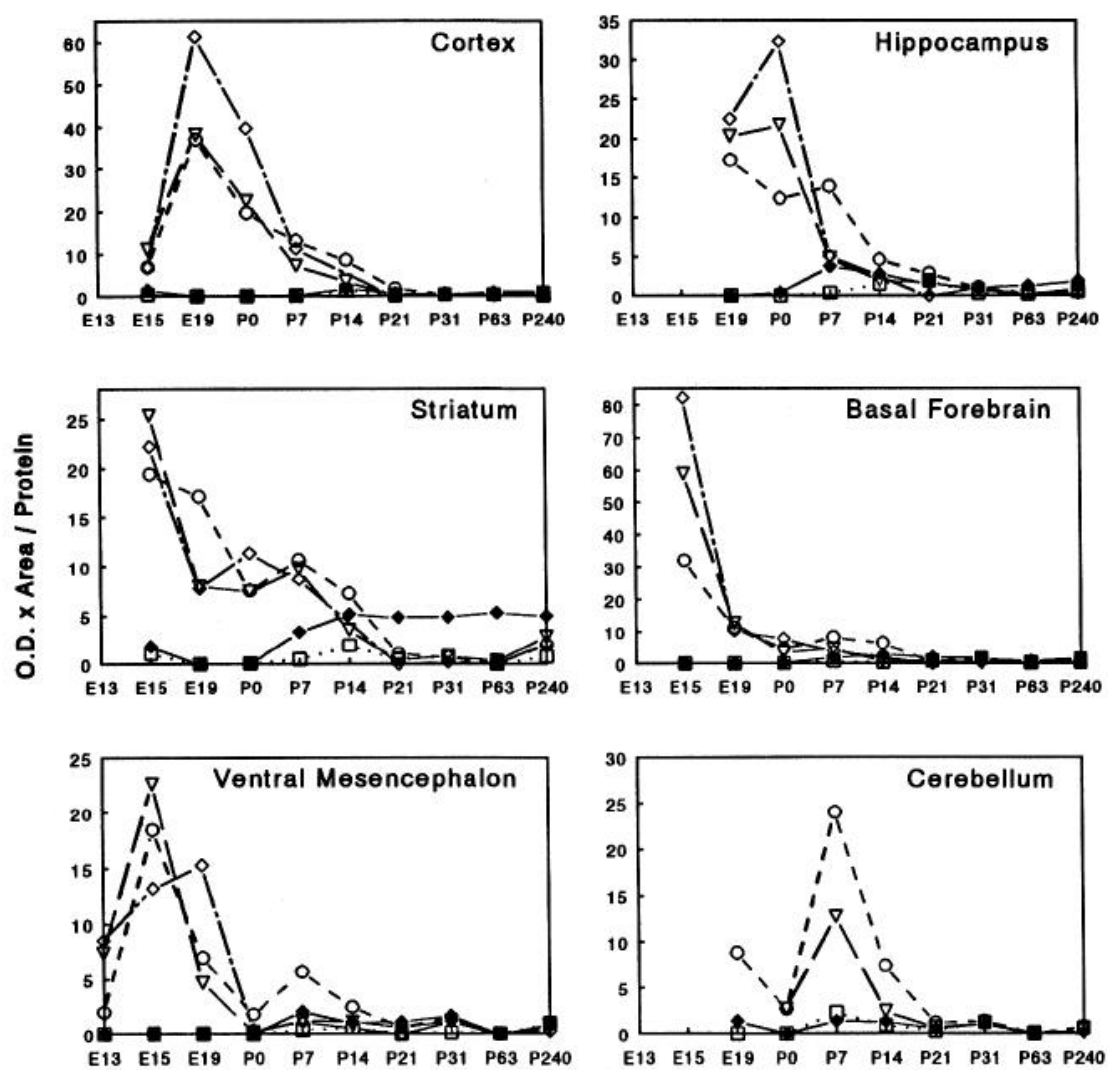

Developmental Age
Figure 6. Quantitation of neurotrophin-induced Trk tyrosine phosphorylation during development of the rat brain. Trk tyrosine phosphorylation signals from 23 experiments including cortex, hippocampus, striatum, basal forebrain, ventral mesencephalon, and cerebellum from rats aged between E13 and P240 were quantitated as described in Materials and Methods. $\square$, control; $\checkmark$, NGF; O, BDNF; $\nabla, \mathrm{NT}-3 ; \diamond$, NT$4 / 5$. duced strong Trk-type receptor and substrate tyrosine phosphorylation. In the adult, only NGF, but not the other neurotrophins, stimulated significant Trk tyrosine phosphorylation. The similarity of the effects of BDNF, NT-3, and NT-4/5 in tissue from six different brain areas suggests that we are observing predominantly the stimulation of TrkB, the only known member of the Trk protein family that has been found to bind and respond to each of these neurotrophins (Berkemeier et al., 1991; Klein et al., 1991b; Soppet et al., 1991; Squinto et al., 1991; Ip et al., 1992). It is possible, however, that some of the responses to NT-3 were mediated by TrkC (Lamballe et al., 1991). Although NT-3 and NT-4/5 stimulate the tyrosine phos- phorylation of TrkA in cultured cells overexpressing this receptor (Berkemeier et al., 1991; Ip et al., 1992), these factors, at the concentrations used in this study, do not stimulate the tyrosine phosphorylation of TrkA in PC12 cells expressing physiological amounts of receptors (Kaplan, unpublished observations).

Lack of significant Trk tyrosine phosphorylation in adult brain tissue incubated with TrkB ligands

The most surprising result of our study is the low level of neurotrophin receptor phosphorylation observed after treatment of adult tissue with BDNF, NT-3, and NT-4/5. Several explana-

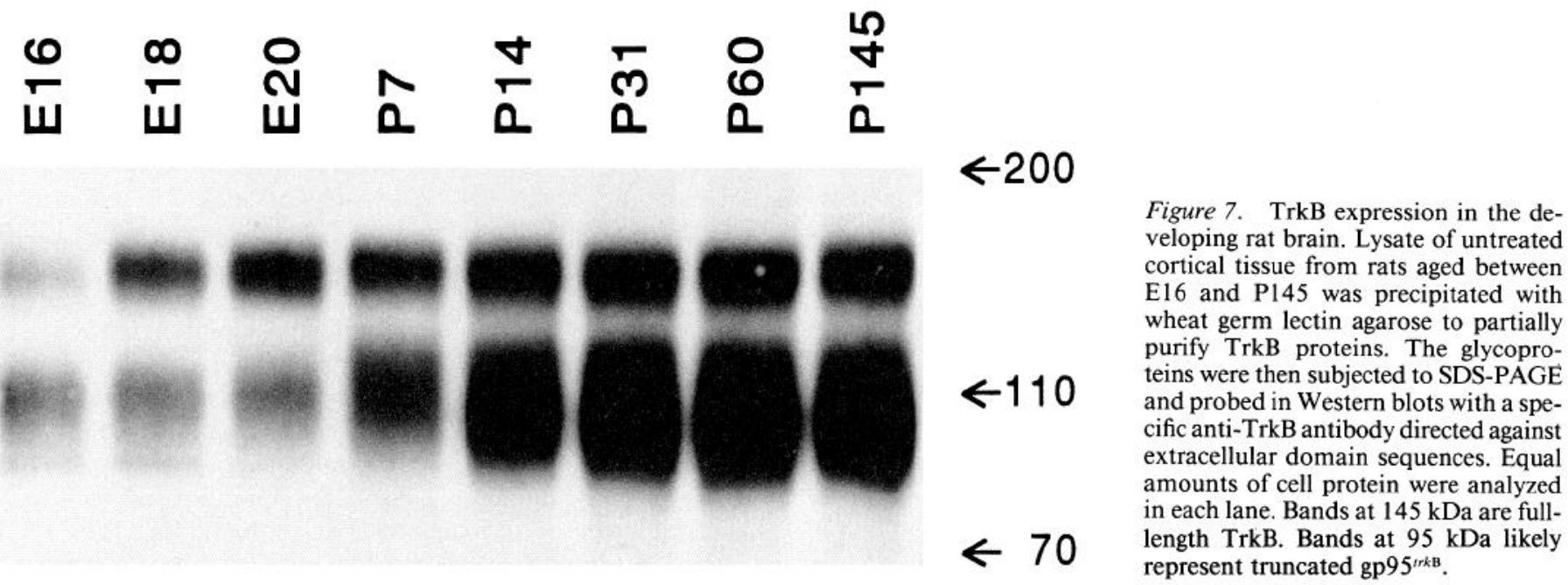


Figure 8. Tyrosine phosphorylation of intracellular targets of Trk activity in embryonic and adult brain tissue. Tissues prepared from embryonic (E16) rat cerebral cortex and adult (P60) hippocampus were incubated for $4 \mathrm{~min}$ at $37^{\circ} \mathrm{C}$ with NGF $(100 \mathrm{ng} / \mathrm{ml})$, BDNF $(200 \mathrm{ng} / \mathrm{ml})$, or NT-3 $(400 \mathrm{ng} / \mathrm{ml})$. After incubation the tissue was lysed and immunoprecipitated with the SNT affinity reagent $\mathrm{p} 13^{\text {sucl }}$-agarose $(A)$, with rabbit anti-Erk $1(B)$, or with mouse antiPLC- $\gamma 1(C)$. Proteins were subjected to SDS-PAGE and analyzed by immunoblotting with anti-Ptyr as described in Materials and Methods. $I g G$, immunoglobulins used in immunoprecipitation. The sample load in each lane corresponded to equal amounts of total protein in the lysate. Reprobing with anti-Erk 1 demonstrated equivalent amounts of Erk 1 in the embryonic and adult samples (data not shown).

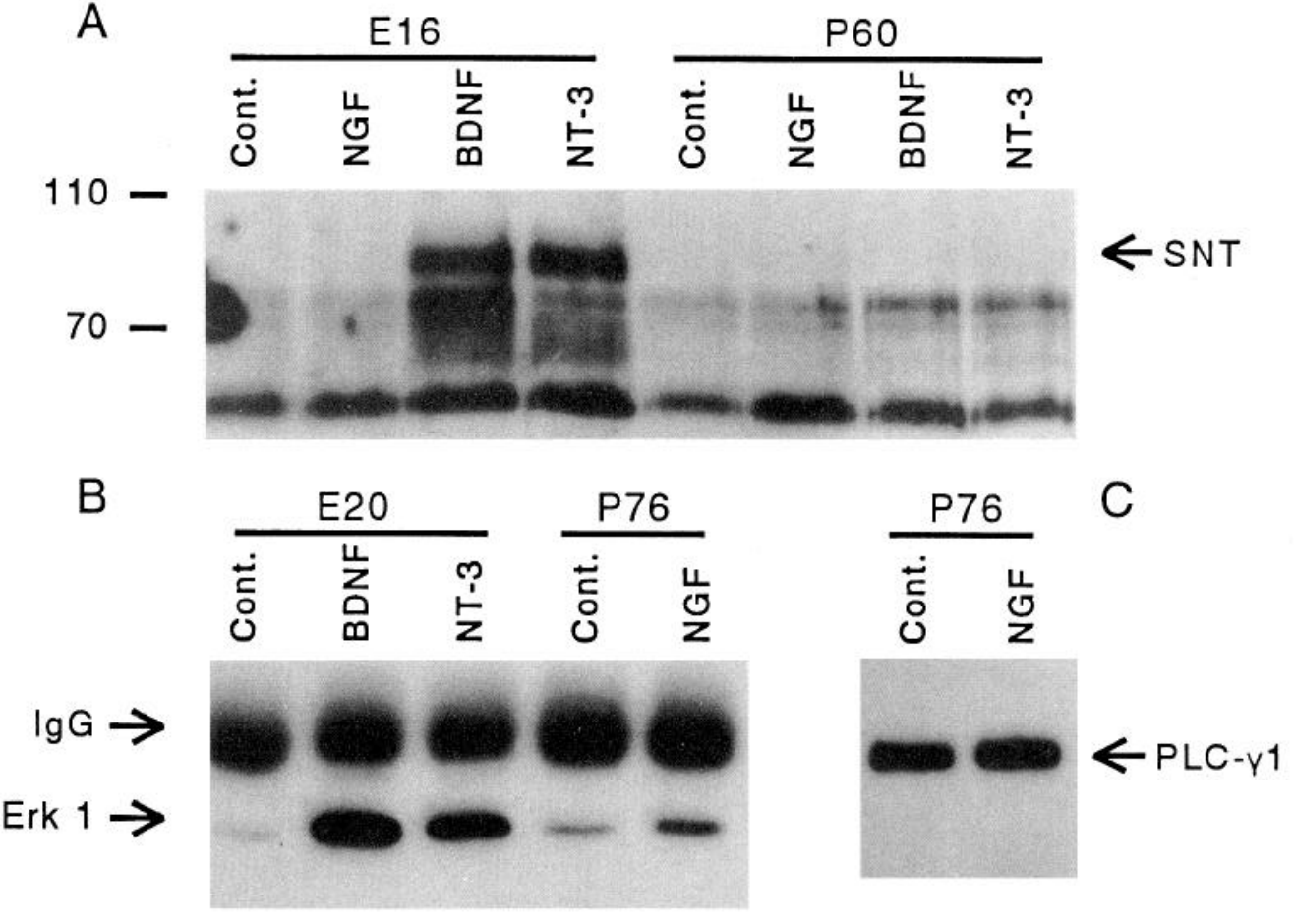

tions may account for this finding. First, these three neurotrophins may not penetrate the microprisms of brain tissue in the in vitro assay. However, addition of high concentrations of BDNF $(10 \mu \mathrm{g} / \mathrm{ml})$ or complete dissociation of the tissue by trituration did not result in significantly enhanced Trk tyrosine phosphorylation responses, nor did different incubation times and temperatures affect this result. Cross-linking experiments have shown that full-length TrkB receptors in hippocampal tissue from adult mice bind BDNF, indicating that exogenously added BDNF was accessible to TrkB in dissected tissue (Soppet et al., 1991; Escandon et al., 1993). Sufficient penetration of the neurotrophins into the microprisms was also indicated by the very effective Trk tyrosine phosphorylation induced by NGF in adult brain, particularly in striatum and hippocampus. Furthermore, the decrease in BDNF, NT-3, and NT-4/5 responses during development occurred in specific brain areas during a relatively short time period (P7-P14), suggesting that the effect was not due to general changes in the properties of aging tissue. We conclude from these observations that the changing patterns of neurotrophin-induced Trk tyrosine phosphorylation in brain slices might reflect events occurring during normal development in vivo.

In situ hybridization and cross-linking data indicate that TrkB is widely expressed in the adult brain, with highest levels in the hippocampus (Klein et al., 1990b; Lamballe et al., 1991; Soppet et al., 1991; Vazquez and Ebendal, 1991). Our data demonstrate the presence of TrkB protein in embryonic, postnatal, and adult brain. Significant TrkB tyrosine phosphorylation responses in embryonic or early postnatal brain but not in adult brain suggest the presence of efficient posttranslational regulatory mechanisms in the adult that control the responsiveness of neurotrophin receptors. These mechanisms might involve specific tyrosine phosphatases that may maintain most TrkB receptors in an inactive state in the presence of neurotrophin. Activated receptors for insulin and epidermal growth factor in the rat are rapidly dephosphorylated by specific phosphatases (Faure et al.,
1992). Dephosphorylation of TrkB (and of TrkB substrates) could be much more effective in adult rats than in younger animals, profoundly changing the balance between phosphorylated and dephosphorylated proteins. Alternatively, the cellular environment for TrkB activation during early development might be different from the adult. Accessory proteins might be required for the formation of functional neurotrophin receptors, as proposed in the case of the NGF receptor for the low-affinity NGF receptor protein $\mathrm{p} 75^{\mathrm{NGFR}}$. This, or other proteins, might play such a role for other neurotrophin receptors during early development. Indeed, changing levels of mRNA for p75 NGFR during early development of the rat cerebellum (Buck et al., 1988) closely resemble the changing responsiveness of cerebellar slices to TrkB ligands as observed in our study. Another possible explanation for the lack of TrkB ligand responses in the adult brain could be downregulation of the tyrosine kinase activity of TrkB or TrkC due to continued exposure of the tissue in the intact adult animal to neurotrophin. Chronic treatment of $\mathrm{PC} 12$ cells with NGF or primary cultures of embryonic rat brain with BDNF markedly downregulates tyrosine phosphorylation of Trk proteins (Kaplan et al., 1991b; B. Knüsel and D. R. Kaplan, unpublished observations). In adult hippocampus and cortex, BDNF mRNA is present at relatively high levels (Hofer et al., 1990; Phillips et al., 1990; Wetmore et al., 1990). BDNF protein is also present in adult pig brain at high concentrations (up to $10 \mu \mathrm{g} / \mathrm{gm}$ tissue) (Barde et al., 1982). This BDNF, if available to TrkB receptors, could result in a continuous turnover of cell surface, ligand-responsive receptors to predominantly unresponsive internalized receptors, and a loss in tissue responsiveness to exogenously added neurotrophin. A similar mechanism might explain why adult hippocampus and basal forebrain, which contain high levels of NGF, exhibit lower responses to NGF than striatum, where the levels of NGF are less (Korsching et al., 1985; Shelton and Reichardt, 1986; Whittemore et al., 1986).

Our own results suggest a mechanism for controlling the re- 
sponsiveness of the TrkB tyrosine kinase in adult brain that may utilize the truncated TrkB receptors lacking the catalytic protein tyrosine kinase domain (Klein et al., 1990a; Middlemas et al., 1991). While the biological function of truncated TrkB is not known, our data are compatible with a negative regulatory role for these proteins in neurotrophin responses. Following ligand binding, the truncated receptors may form inactive heterodimers with full-length TrkB receptor. Homodimer formation between full-length Trk receptors is required for neurotrophinmediated signal transduction (Jing et al., 1992). Alternatively, truncated TrkB, which may be incapable of transmitting neurotrophin signals, might directly compete with the full-length receptors for ligand. Our results show that the amount of truncated, relative to full-length, TrkB receptors was elevated in tissues from developmental stages that exhibited decreased responsiveness to TrkB ligands.

Irrespective of the mechanism of downregulation of the tyrosine phosphorylation response to TrkB ligands in adult brain tissue, the functional significance of this low level of responsiveness is unknown. In cell cultures containing basal forebrain cholinergic neurons, BDNF is more effective than NGF in stimulating cholinergic development at early developmental stages, while NGF is more effective at later stages (Alderson et al., 1990; Knüsel et al., 1991). Thus, inversely changing responsiveness to BDNF and NGF, as evident in our present findings, is also obscrved at the cellular level with sclected brain ncurons developing in culture. We have previously shown that in the adult rat, repeated intraventricular injections of BDNF after axonal transection of the basal forebrain cholinergic neurons, unlike NGF injections, only partially protect the cholinergic cell bodies from degeneration (Knüsel et al., 1992a). The limited effect of BDNF in this model system of neuronal degeneration probably reflects the reduced capability of BDNF to stimulate Trk-type receptors in these neurons when compared to NGF. It is possible that BDNF is not required for normal adult brain function. Maintaining high levels of receptor and neurotrophin in hippocampus and other brain areas might allow tissues to respond rapidly to events that may require BDNF signals, such as recovery from lesion (Ernfors et al., 1991; Isackson et al., 1991; Zafra et al., 1991; Dugich-Djordjevic et al., 1992; Frisen et al., 1992; Beck et al., 1993). In adult rat hippocampus subjected to lesion by kainate injection, TrkB tyrosine phosphorylation is induced (B. Knüsel, M. Dugich-Djordjevic, F. Hefti, and D. R. Kaplan, unpublished observations), suggesting that specific experimental manipulations in adult animals partially restores responses to TrkB ligands.

Developmental regulation of the response of brain tissue to the TrkB ligands $B D N F, N T-3$, and $N T-4 / 5$

Our data show a particularly high level of responsiveness to TrkB and TrkC ligand stimulation during an important period of early development of the CNS. Peaks of BDNF-, NT-3-, and NT-4/5-induced Trk tyrosine phosphorylation in mesencephalon, cortex, and cerebellum were observed at E15, E19, and $\mathrm{P} 7$, respectively. This responsiveness remained pronounced until the first week after birth in cortex and mesencephalon and 2-3 weeks after birth in cerebellum. For each of these tissues this period corresponds to the end of the most intense neuronal proliferation and coincides with the time of maximal neuronal migration (Altman, 1972; Bayer et al., 1991; Jacobson, 1991). In the cerebellum, most granule cells arise postnatally in the external granule cell layer and then migrate to the internal gran- ule cell layer (Jacobson, 1991). Reflecting these processes, the external granule cell layer first expands and then decreases in size before ultimately disappearing. The postnatal pattern of BDNF-, NT-3-, and NT-4/5-induced tyrosine phosphorylation in cerebellum in our study corresponds exactly to the time course of the changing size of the external granule cell layer (Jacobson, 1991). A recent study indeed reports enhanced survival response of cells of the external granule cell layer of the rat cerebellum in culture to BDNF and of more mature granule cells to NT-3 (Segal et al., 1992).

In cortex and hippocampus maximal responses to $\operatorname{TrkB}$ and TrkC ligands were seen shortly before and immediately after birth. While in situ hybridization experiments indicate highest levels of TrkB and TrkC mRNA expression approximately 12 weeks later (Dugich-Djordjevic et al., 1993; Ringstedt et al., 1993), proteins likely to be involved in neuronal migration, including a specific form of the neural cell adhesion molecule and other transiently expressed glycoproteins, are predominantly expressed during the time of maximal neurotrophin responsiveness (Kuchler et al., 1989; Seki and Arai, 1991). In contrast, mRNAs for typical markers of neurite outgrowth and synaptogenesis increase at much later times (Dani et al., 1991; Mahalik et al., 1992). The similarity of conserved extracellular domains of the Irk molecules with a cell adhesion motif found in mammals and in Drosophila has invited the speculation that TrkB could be dircetly involved in mechanisms of cell adhesion (Schneider and Schweiger, 1991). The presence of two principal forms of TrkB, only one of which includes the intracellular tyrosine kinase domain, might indicate a dual function of this protein in the brain. During early development TrkB might not only guide neurons along their migratory path but, in the same cells, may facilitate this migration by stimulating intracellular functions participating in this process. Later in life, the two functions of TrkB could be more segregated, explaining the selective increase in the expression of truncated $\operatorname{TrkB}$ in lesion models of adult spinal cord and hippocampus (Frisen et al., 1992; Beck et al., 1993).

\section{Forebrain cholinergic neurons and the NGF response}

While the tyrosine phosphorylation responses to BDNF, NT-3, and $\mathrm{NT}-4 / 5$ in the various tested brain tissues decreased postnatally after initial very high levels, responses to NGF increased early postnatally. The highest NGF response was observed in the striatum where it reached adult levels at 2 weeks of age. This response most likely occurs in the striatal cholinergic interneurons, which in culture have been shown to respond to NGF during early development (Martinez et al., 1985; Hartikka and Hefti, 1988) and which in the adult brain express trkA mRNA (Holtzman et al., 1992; Venero, Knüsel, Beck, and Hefti, unpublished observations). Maximal stimulation of Trk tyrosine phosphorylation in striatal tissue was obtained at $10-30$ $\mathrm{ng} / \mathrm{ml}$ NGF. This concentration is about 10 -fold higher than the concentration necessary for maximal stimulation of ChAT activity or Trk phosphorylation in basal forebrain cultures (Knüsel et al., 1990, 1992b). Our results with the two experimental systems might reflect differences between cultured embryonic cells and adult fresh tissue. Alternatively, they might be due to differences in the configurations of functional NGF receptors in cholinergic neurons of the basal forebrain and the striatum, possibly related to the absence, in striatum, of p $75^{\mathrm{NGFR}}$ (Gage et al., 1989; Springer et al., 1990). Both TrkA and p $75^{\text {NGFR }}$ 
proteins may be required for high-affinity NGF binding (Hempstead et al., 1991).

Substantial NGF-induced Trk phosphorylation signals were observed not only in postnatal striatum but also in hippocampus and basal forebrain, the two brain areas containing terminals and cell bodies of the NGF-responsive basal forebrain cholinergic cells, respectively (Hefti et al., 1989, review). Degeneration of these cells, which are critically involved in learning and memory (Nilsson et al., 1992), is believed to be at least partially responsible for the loss of cognitive functions characteristic of Alzheimer's disease. Our results confirm that neurons of the basal forebrain respond to NGF and remain responsive in the adult, as previously shown in lesioned animals injected with NGF (Hefti et al., 1989; Koliatsos et al., 1991). In agreement with our results with fresh tissue of adult brain, repeated brain injections of NGF but not of BDNF have been found to stimulate the expression of ChAT in lesioned and unlesioned adult rat brain neurons (Venero et al., 1993). It is presently not known whether BDNF or other TrkB ligands can similarly stimulate other differentiated properties of normal adult brain cells.

\section{Ligand-induced activation of other cellular proteins}

Our methods to analyze ligand-induced tyrosine phosphorylation in microslices of fresh brain tissue under physiological conditions can equally be applied to other receptor tyrosine kinases and intracellular targets of their actions. Using these methods, we analyzed tyrosine phosphorylation of Erk 1, PLC- $\gamma 1$, and SNT after incubation of brain slices with neurotrophins. While NGF very pronouncedly increased the tyrosine phosphorylation of Erk 1 in adult tissue, tyrosine phosphorylation of PLC- $\gamma 1$ was only minimally increased. This difference could be due to the high baseline level for PLC- $\gamma 1$ observed in untreated control samples. Surprisingly, we did not observe NGF-induced tyrosine phosphorylation of SNT, which has previously been shown to become phosphorylated upon neurotrophin binding to Trktype receptors (Rabin et al., 1993). Incubation of embryonic tissue with the TrkB ligands BDNF and NT-3, however, greatly stimulated the tyrosine phosphorylation of SNT. This lack of NGF-induced SNT tyrosine phosphorylation in adult tissue compared to the response observed in TrkB ligand-treated embryonic tissue may reflect the quantitatively low levels of TrkA activity in the adult. Alternatively, in adult tissues, TrkA may utilize Erk 1 and PLC- $\gamma 1$ but not SNT to transmit NGF signals. Our results emphasize the need of further studies, using these and other methods, to analyze the physiological correlates of neurotrophin function and the intracellular pathways utilized in the developing and adult mammalian brain.

\section{References}

Alderson RF, Alterman AL, Barde YA, Lindsay RM (1990) Brainderived neurotrophic factor increases survival and differentiated functions of rat septal cholinergic neurons in culture. Neuron 5:297-306.

Altman J (1972) Postnatal development of the cerebellar cortex in the rat. I. The external germinal layer and the transitional molecular layer. J Comp Neurol 145:353-398.

Barbacid M, Lamballe F, Pulido D, Klein R (1991) The trk family of tyrosine protein kinase receptors. Biochim Biophys Acta 1072:115127.

Barde Y-A, Edgar D, Thoenen H (1982) Purification of a new neurotrophic factor from mammalian brain. EMBO J 1:549-553.

Bayer SA, Altman J, Russo RJ, Dai X, Simmons JA (1991) Cell migration in the rat embryonic neocortex. J Comp Neurol 307:499516.

Beck KD, Lamballe F, Klein R, Barbacid M, Schauwecker PE, McNeill
TH, Finch CE, Hefti F, Day JR (1993) Induction of noncatalytic TrkB neurotrophin receptors during axonal sprouting in the adult hippocampus. J Neurosci 13:4001-4014.

Berkemeier LR, Winslow JW, Kaplan DR, Nikolics K, Goeddel DV, Rosenthal A (1991) Neurotrophin-5: a novel neurotrophic factor that activates trk and trkB. Neuron 7:857-866.

Boulton TG, Nye SH, Robbins DJ, Ip NY, Radziejewska E, Morgenbesser SD, Depinho RA, Panayootatos N, Cobb MH, Yancopoupos GD (1991) ERKs: a family of protein-serine/threonine kinases that are activated and tyrosine phosphorylated in response to insulin and NGF. Cell 65:663-675.

Buck CR, Martinez HJ, Chao MV, Black IB (1988) Differential expression of the nerve growth factor receptor gene in multiple brain areas. Dev Brain Res 44:259-268.

Chao MV (1992) Neurotrophin receptors: a window into neuronal differentiation. Neuron 9:583-593.

Chen RH, Sarnecki C, Blenis J (1992) Nuclear localization and regulation of erk- and rsk-encoded protein kinases. Mol Cell Biol 12: 915-927.

Cordon-Cardo C, Tapley P, Jing S, Nandure V, O'Rourke E, Lamballe F, Kovary K, Klein R, Jones KR, Reichardt LF, Barbacid M (1991) The trk tyrosine protein kinase mediates the mitogenic properties of nerve growth factor and neurotrophin-3. Cell 66:173-183.

Dani JW, Armstrong DM, Benowitz LI (1991) Mapping the development of the rat brain by GAP-43 immunocytochemistry. Neuroscience 40:277-287.

Dugich-Djordjevic MM, Tocco G, Pasinetti GM, Baudry M, Lapchak PA, Hefti F (1992) Regionally specific and rapid increases in brainderived neurotrophic factor messenger RNA in the adult rat brain following seizures induced by systemic administration of kainic acid. Neuroscience 47:303-315.

Dugich-Djordjevic MM, Ohsawa F, Hefti F (1993) Transient elevation in expression of catalytic trkB mRNA during postnatal development of the rat brain. Neuroreport 4:1091-1094.

Ebendal T (1992) Function and evolution in the NGF family and its receptors. J Neurosci Res 32:461-470.

Ernfors P, Wetmore C, Olson L, Persson H (1990) Identification of cells in rat brain and peripheral tissues expressing mRNA for members of the nerve growth factor family. Neuron 5:511-526.

Ernfors P, Bengzon J, Kokaia Z, Persson H, Lindvall O (1991) Increased levels of messenger RNAs for neurotrophic factors in the brain during kindling epileptogenesis. Neuron 7:165-176.

Ernfors P, Merlio J-P, Persson H (1992) Cells expressing mRNA for neurotrophins and their receptors during embryonic rat development. Eur J Neurosci 4:1140-1158.

Escandon E, Burton LE, Szönyi E, Nikolics K (1993) Characterization of neurotrophin receptors by affinity crosslinking. J Neurosci Res 34: 601-613.

Faure R, Baquiran G, Bergeron JJM, Posner BI (1992) The dephosphorylation of insulin and epidermal growth factor receptors. J Biol Chem 267:11215-11221.

Frisen J, Verge VMK, Cullheim S, Persson H, Fried K, Middlemas DS, Hunter T, Hauokfelt T, Risling M (1992) Increased levels of trkB mRNA and trkB protein-like immunoreactivity in the injured rat and cat spinal cord. Proc Natl Acad Sci USA 89:11282-11286.

Gage FH, Batchelor P, Chen KS, Chin D, Higgins GA, Koh S, Deputy S, Rosenberg MB, Fischer W, Björklund A (1989) NGF receptor reexpression and NGF-mediated cholinergic neuronal hypertrophy in the damaged adult neostriatum. Neuron 2:1177-1184.

Hartikka J, Hefti F (1988) Comparison of nerve growth factor's effects on development of septum, striatum, and nucleus basalis cholinergic neurons in vitro. J Neurosci Res 21:352-364.

Hefti F, Hartikka J, Knüsel B (1989) Function of neurotrophic factors in the adult and aging brain and their possible use in the treatment of neurodegenerative diseases. Neurobiol Aging 10:515-533.

Hempstead BL, Martin-Zanca D, Kaplan DR, Parada LF, Chao MV (1991) High-affinity NGF binding requires coexpression of the trk proto-oncogene and the low-affinity NGF receptor. Nature 344:339341 .

Hempstead BL, Rabin SJ, Kaplan L, Reid S, Parada LF, Kaplan DR (1992) Overexpression of the trk tyrosine kinase rapidly accelerates nerve growth factor-induced differentiation. Neuron 9:883-896.

Hofer M, Pagliusi SR, IIohn A, Leibrock J, Barde YA (1990) Regional distribution of brain-derived neurotrophic factor $\mathrm{mRNA}$ in the adult mouse brain. EMBO J 9:2459-2464. 
Holtzman DM, Li Y, Parada LF, Kinsman S, Chen C-K, Valletta JS, Zhou J, Long JB, Mobley WC (1992) p140trk mRNA marks NGF. responsive forehrain neurons: evidence that trk gene expression is induced by NGF. Neuron 9:465-478.

Ip NY, Ibanez CF, Nye SH, McClain J, Jones P, Gies DR, Belluscio L, LeBeau MM, Espinosa R III, Squinto SP, Persson H, Yancopoulos GD (1992) Mammalian neurotrophin-4: structure, chromosomal localization, tissue distribution, and receptor specificity. Proc Natl Ac̈d Sci USA 89:3060-3064.

Isackson PJ, Huntsman MM, Murray KD, Gall CM (1991) BDNF mRNA expression is increased in adult rat forebrain after limbic seizures: temporal patterns of induction distinct from NGF. Neuron $6: 937-948$.

Jacobson M (1991) Developmental neurobiology. New York: Plenum.

Jing S, Tapley P, Barbacid M (1992) Nerve growth factor mediates signal transduction through trk homodimers. Neuron 9:1067-1079.

Kaplan DR, Morrison DK, Wong G, McCormick F, Williams I.T (1990) PDGF $\beta$-receptor stimulates tyrosine phosphorylation of GAP and association of GAP with a signaling complex. Cell 61:125-133.

Kaplan DR, Hempstead BL, Martin-Zanca D, Chao MV, Parada LF (1991a) The trk proto-oncogene product: a signal transducing receptor for nerve growth factor. Science 252:554-558.

Kaplan DR, Martin-Zanca D, Parada LF (1991b) Tyrosine phosphorylation and tyrosine kinase activity of the trk proto-oncogene product induced by NGF. Nature 350:158-160.

Kim U-H, Fink D Jr, Kim HS, Park DJ, Contreras ML, Guroff G, Rhee SG (1991) Nerve growth factor stimulates phosphorylation of phospholipase C- $\gamma$ in PC12 cells. J Biol Chem 266:1359-1362.

Klein R, Conway D, Parada LF, Barbacid M (1990a) The trkB tyrosine protein kinase gene codes for a second neurogenic receptor that lacks the catalytic kinase domain. Cell 61:647-656.

Klein R, Martin-Zanca D, Barbacid M, Parada LF (1990b) Expression of the tyrosine kinase receptor gene trkB is confined to the murine embryonic and adult nervous system. Development 109:845-850.

Klein R, Jing S, Nanduri V, O'Rourke E, Barbacid M (1991a) The trk proto-oncogene encodes a receptor for nerve growth factor. Cell 65:189-197.

Klein R, Nanduri V, Jing S, Lamballe F, Tapley P, Bryant S, CordonCardo C, Jones KR, Reichardt I.F, Barhacid M (1991h) The trkB tyrosine protein kinase is a receptor for brain-derived neurotrophic factor and neurotrophin-3. Cell 66:395-404.

Knüsel B, Burton LE, Longo FM, Mobley WC, Koliatsos VE, Price DL, Hefti F (1990) Trophic actions of recombinant human nerve growth factor on cultured rat embryonic CNS cells. Exp Neurol 110:274 283.

Knüsel B, Winslow JW, Rosenthal A, Burton LE, Seid DP, Nikolics K, Hefti F (1991) Promotion of central cholinergic and dopaminergic neuron differentiation by brain-derived neurotrophic factor but not neurotrophin-3. Proc Natl Acad Sci USA 88:961-965.

Knüsel B, Beck KD, Winslow JW, Rosenthal A, Burton LE, Widmer HR, Nikolics K, Hefti F (1992a) Brain-derived neurotrophic factor administration protects basal forebrain cholinergic but not nigral dopamincrgic neurons from degenerative changes after axotomy in the adult rat brain. J Neurosci 12:4391-4402.

Knüsel B, Rabin S, Widmer HR, Hefti F, Kaplan DR (1992b) Neurotrophin-induced trk receptor phosphorylation and cholinergic neuron response in primary cultures of embryonic rat brain neurons. Neuroreport 3:885-888.

Koliatsos VE, Clatterbuck RE, Nauta HJW, Knüsel B, Burton LE, Hefti F, Mobley WC, Price DL (1991) Human nerve growth factor prevents degeneration of basal forebrain cholinergic neurons in primates. Ann Neurol 30:831-840.

Korsching S, Auburger G, Heumann R, Scott J, Thoenen H (1985) Levels of nerve growth factor and its mRNA in the central nervous system of the rat correlate with cholinergic innervation. EMBO J 4:1389-1393

Kuchler S, Rougon G, Marschal P, Lehmann S, Reeber A, Vincendon G, Zanetta J-P (1989) Location of a transiently expressed glycoprotein in developing cerebellum delineating its possible ontogenetic roles. Neuroscience 33:111-124.

Lamballe F, Klein R, Barbacid M (1991) TrkC, a new member of the trk family of tyrosine protein kinases, is a receptor for neurotrophin3. Cell 66:967-979.

Leibrock J, Lottspeich F, Hohn A, Hofer M, Hengerer B, Masiakowski
P, Thoenen H, Barde Y-A (1989) Molecular cloning and expression of brain-derived neurotrophic factor. Nature 341:149-152.

Lindsay RM, Rohrer H (1985) Placodal sensory neurons in culture: nodose ganglion neurons are unresponsive to NGF, lack NGF receptors but are supported by a liver-derived neurotrophic factor. Dev Biol 112:30-48.

Mahalik TJ, Carrier A, Owens GP, Clayton G (1992) The expression of GAP43 mRNA during the late embryonic and early postnatal development of the CNS of the rat: an in situ hybridization study. Dev Brain Res 67:75-83.

Maisonpierre PC, Belluscio L, Friedman B, Alderson RF, Wiegand SJ, Furth RF, Lindsay RM, Yancopoulos GD (1990) NT-3, BDNF, and NGF in the developing rat nervous system: parallel as well as reciprocal patterns of expression. Neuron 5:501-509.

Martin-Zanca D, Oskam R, Mitra G, Copeland T, Barbacid M (1989) Molecular and biochemical characterization of the human trk protooncogene. Mol Cell Biol 9:24-33.

Martinez HJ, Dreyfus CF, Jonakait GM, Black IB (1985) Nerve growth factor promotes cholinergic development in brain striatal cultures. Proc Natl Acad Sci USA 83:7777-7781.

Merlio J-P, Ernfors P, Jaber M, Persson H (1992) Molecular cloning of rat $t r k \mathrm{C}$ and distribution of cells expressing messenger RNAs for members of the trk family in the rat central nervous system. Neuroscience 51:513-532.

Middlemas DS, Lindberg RA, Hunter T (1991) trkB, a neural receptor protein-tyrosine kinase: evidence for a full-length and two truncated receptors. Mol Cell Biol 11:143-153.

Miyasaka T, Sternberg D, Miyasaka J, Sherline P, Saltiel AR (1991) Nerve growth factor stimulated protein tyrosine phosphorylation in PC12 pheochromocytoma cells. Proc Natl Acad Sci USA 88:26532657.

Nilsson OG, Leanza G, Rosenblad C, Lappi DA, Wiley RG, Björklund A (1992) Spatial learning impairments in rats with selective immunolesion of the forebrain cholinergic system. Neuroreport 3:10051008

Ohmichi M, Decker SJ, Pang L, Saltiel AR (1991) Nerve growth factor binds to the $140 \mathrm{kd}$ trk proto-oncogene product and stimulates its association with the src homology domain of phospholipase $\mathrm{C}$ gamma 1. Biochem Biophys Res Commun 179:217-223.

Park D, Rhee SG (1992) Phosphorylation of Nck in response to a variety of receptors, phorbol myristate acetate, and cyclic AMP. Mol Cell Biol 12:5816-5823.

Phillips HS, Hains JM, Laramee GR, Rosenthal A, Winslow JW (1990) Widespread expression of BDNF but not NT3 by target areas of basal forebrain cholinergic neurons. Science 250:290-292.

Rabin SJ, Cleghon V, Kaplan DR (1993) SNT, a differentiation-specific target of neurotrophic factor-induced tyrosine kinase activity in neurons and PC12 cells. Mol Cell Biol 13:2203-2213.

Raffioni S, Bradshaw RA (1992) Activation of phosphatidylinositol 3-kinase by epidermal growth factor, basic fibroblast growth factor, and nerve growth factor in PC12 pheochromocytoma cells. Proc Natl Acad Sci USA 89:9121-9125.

Ringstedt T, Lagercrantz H, Persson H (1993) Expression of members of the trk family in the developing postnatal rat brain. Dev Brain Res 72:119-131

Rozakis-Adcock M, McGlade J, Mbamalu G, Pelicci G, Daly R, Li W, Batzer A, Thomas S, Brugge J, Pelicci PG, Schlessinger J, Pawson T (1992) Association of the Shc and Grb2/Sem5 SH2-containing proteins is implicated in activation of the Ras pathway by tyrosine kinases. Nature 360:689-692.

Schecterson LC, Bothwell M (1992) Novel roles for neurotrophins are suggested by BDNF and NT-3 mRNA expression in developing neurons. Neuron 9:449-463.

Schneider R, Schweiger M (1991) A novel modular mosaic of cell adhesion motifs in the extracellular domains of the neurogenic trk and trkB tyrosine kinase receptors. Oncogene 6:1807-1811.

Segal RA, Takahashi H, McKay RDG (1992) Changes in neurotrophin responsiveness during the development of cerebellar granule neurons. Neuron 9:1041-1052.

Seki T, Arai Y (1991) Expression of a highly polysialylated NCAM in the neocortex and piriform cortex of the developing and adult rat. Anat Embryol (Berl) 184:395-401.

Shelton DL, Reichardt LF (1986) Studies on the expression of the $\beta$ nerve growth factor (NGF) gene in the central nervous system: level and regional distribution of NGF mRNA suggest that NGF functions 
as a trophic factor for several distinct populations of neurons. Proc Natl Acad Sci USA 83:2714-2718.

Soltoff SP, Rabin SL, Cantley LC, Kaplan DR (1992) Nerve growth factor promotes the activation of phosphatidylinositol 3-kinase and its association with the trk tyrosine kinase. J Biol Chem 267:1747217477.

Soppet D, Escandon E, Maragos I, Kaplan DR, Hunter T, Nikolics K, Parada LF (1991) The neurotrophic factors BDNF and NT-3 are ligands for the trkB tyrosine kinase receptor. Cell 65:895-903.

Springer JE, Robbins E, Meyer S, Baldino FJ, Lewis ME (1990) Localization of nerve growth factor receptor mRNA in the rat basal forebrain with in situ hybridization histochemistry. Cell Mol Neurobiol 10:33-39.

Squinto SP, Stitt TN, Aldrich TH, Davis SM, Bianco SM, Rdziejewski C, Glass DJ, Masiakowski P, Furth ME, Valenzuela DM, DiStefano PS, Yancopoulos GD (1991) trkB encodes a functional receptor for brain-derived neurotrophic factor and neurotrophin-3 but not NGF. Cell 65:885-893.

Suh PG, Ryu SH, Choi WC, Lee KY, Rhee SG (1988) Monoclonal antibodies to three phospholipase $\mathrm{C}$ isozymes from bovine brain. $\mathrm{J}$ Biol Chem 263:14497-14504.

Timmusk T, Belluardo N, Metsis M, Persson H (1993) Widespread and developmentally regulated expression of neurotrophin-4 mRNA in rat brain and peripheral tissues. Eur J Neurosci 5:605-613.

Vazquez ME, Ebendal T (1991) Messenger RNAs for trk and the lowaffinity NGF receptor in rat basal forebrain. Neuroreport 2:593-596.

Venero JL, Knüsel B, Beck KD, Hefti F (1993) Expression of neurotrophin and trk receptor genes in adult rats with fimbria transec- tions: effect of intraventricular NGF and BDNF administration. Neuroscience, in press.

Vetter ML, Martin-Zanca D, Parada LF, Bishop JM, Kaplan DR (1991) Nerve growth factor rapidly stimulates tyrosine phosphorylation of phospholipase C-gammal by a kinase activity associated with the product of trk protooncogene. Proc Natl Acad Sci USA 88:56505654.

Wetmore C, Ernfors P, Persson H, Olson L (1990) Localization of brain-derived neurotrophic factor mRNAS to neurons in the brain by in situ hybridization. Exp Neurol 109:141-152.

Whittemore SR, Ebendal T, Larkfors L, Olson L, Seiger A, Stromberg I, Persson $H$ (1986) Developmental and regional expression of $\beta$ nerve growth factor messenger RNA and protein in the rat central nervous system. Proc Natl Acad Sci USA 83:817-821.

Widmer HR, Knüsel B, Hefti F (1992) Stimulation of phosphatidylinositol hydrolysis by brain-derived neurotrophic factor and neurotrophin-3 in rat cerebral cortical neurons developing in culture. J Neurochem 59:2113-2124.

Widmer HR, Kaplan DR, Rabin SJ, Beck KD, Hefti F, Knüsel B (1993) Rapid phosphorylation of phospholipase-C $\gamma 1$ by BDNF and NT-3 in cultures of embryonic rat cortical neurons. J Neurochem 60:21112123.

Zafra F, Castren E, Thoenen H, Lindholm D (1991) Interplay between glutamate and gamma-aminobutyric acid transmitter systems in the physiological regulation of brain-derived neurotrophic factor and nerve growth factor synthesis in hippocampal neurons. Proc Natl Acad Sci USA 88:10037-10041. 